\title{
The Interstitial Metabolism of Galcium in the Bones and Teeth of Rats
}

\author{
By D. H. TOMLIN \\ Department of Physics, University of Reading \\ KATHLEEN M. HENRY AND S. K. KON \\ National Institute for Research in Dairying, University of Reading \\ (Received 21 August 1954)
}

The metabolism of calcium in the bones of growing animals may be classified broadly into two groups of processes, $(a)$ the growth of the bones by accretion of new bone mineral at certain regions of the surface together with resorption at certain other regions, and $(b)$ interstitial processes involving turnover of $\mathrm{Ca}$ throughout the remaining volume of the mineral phase of bone.

When radioactive $\mathrm{Ca}$ is given to animals in the diet continuously during a specific period, both these effects can be seen in autoradiographs subsequently prepared from longitudinal sections of the bones ('Tomlin, Henry \& Kon, 1953). The mechanism of the surface effects due to growth is by now well known, but the mechanisms involved in the volume effect, shown in the autoradiographs by a comparatively weak reaction throughout regions corresponding to the pre-existing bone mineral, are not yet fully understood.

Until recently it was believed that in growing animals equilibrium between radioactive $\mathrm{Ca}$ introduced into the circulation in the food or by injection, and the $\mathrm{Ca}$ in the bone mineral, is reached within quite short times. Exchange of $\mathrm{Ca}$ ions between the bone-crystal surfaces and the body fluids, together with recrystallization, involving an interchange of the surface ions with those in the interior of the crystals, was supposed to account for this approach to equilibrium. A full discussion of these processes, as understood at the time, is given in a comprehensive review by Neuman \& Neuman (1953).

The autoradiographs previously published by Tomlin et al. (1953) show quite clearly that such an approach to equilibrium in the long bones of the rat is an extremely slow process, even in very young animals, and this view has been put forward also by Carlsson (1952) and by Bauer (1954). Nevertheless, the interstitial incorporation of $\mathrm{Ca}$ in cortical bone in reasonably short time intervals is readily observable and measurable, and is no doubt an important aspect of Ca metabolism.

There is certainly a need for experimental study of the process in order to establish the nature of the mechanisms involved. The experiments reported here were designed to provide a contribution to the understanding of these mechanisms. At a later date it is hoped to publish further work in which the effects on interstitial metabolism of dietary changes are being studied. 


\section{EXPERIMENTAL}

Animals and diet. Twenty male rats of our own breeding were used. They were weaned on to the low-Ca diet (diet 24I) of Henry \& Kon (r953) or this diet supplemented with $0.016 \% \mathrm{CaCO}_{3}$ containing ${ }^{45} \mathrm{Ca}$. The specific activity of the radioactive $\mathrm{CaCO}_{3}$ was such that $100 \mathrm{~g}$ of diet contained approximately $5 \mu \mathrm{c}$. The diets contained about $0.15 \%$ P. The animals were divided into three groups. Group I (two rats) was given the radioactive diet from weaning for 14 weeks and then killed. Group 2 (eight rats) was weaned on to diet $24 \mathrm{I}$ and after $\mathrm{I} 2$ weeks given the radioactive diet; pairs of rats were killed $4,7, I_{4}$ and 28 days after the change of diet. Group 3 (ten rats) was weaned on to diet $24 \mathrm{I}$; after 12 weeks the animals were given the radioactive

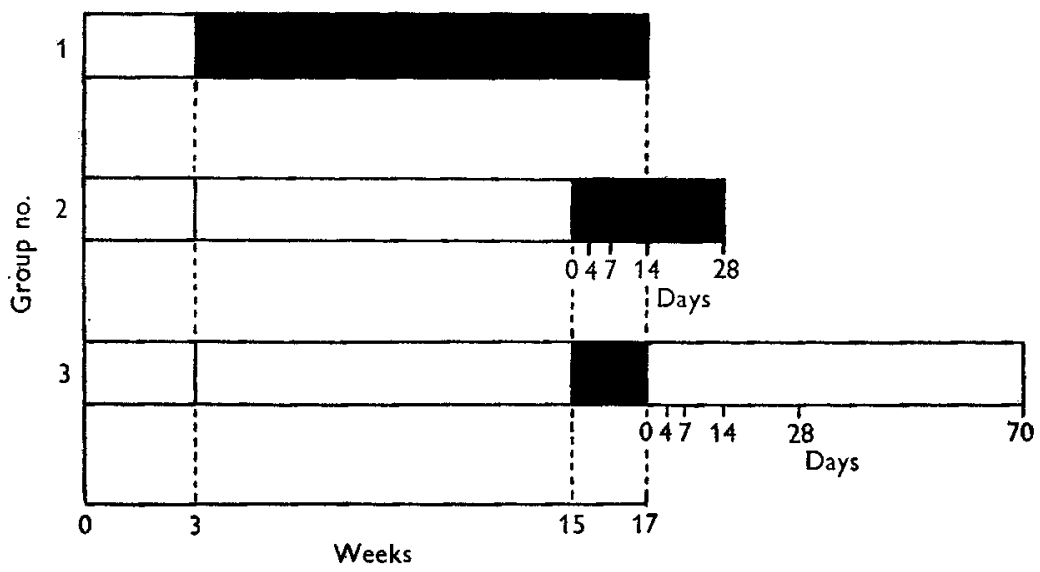

Fig. I. Periods during which radioactive diet was given to the three experimental groups of rats, and days on which rats in groups 2 and 3 were killed.

diet for 2 weeks and then diet 241 again; pairs of rats were killed 4, 7, 14, 28 and 70 days after this change. The treatments of the three groups are presented in a concise manner in Fig. I, the shaded areas show the periods during which the rats were given the radioactive diet. When the rats were killed as much blood as possible was taken by heart puncture from each pair and pooled for serum-Ca studies. The femora, tibiae, humeri and skulls were removed and prepared for autoradiography as described below.

Method and experimental design. The quantitative result sought was a measurement of the amount of radioactive dietary Ca taken up interstitially by the cortical bone in the animals of groups 2 and 3 , expressed as a percentage of the total bone $\mathrm{Ca}$. The measurements were to refer to regions of the cortex not participating in surface accretion (i.e in physical growth) and therefore incorporating $\mathrm{Ca}$ only by a volume or interstitial process. The desired information was obtained by comparing the specific activity $\alpha_{2}$ of such a region of cortical bone in an animal of group 2 that had received the radioactive diet for a period $t$, with the specific activity $\alpha_{1}$, which the same region of bone would have had if all the $\mathrm{Ca}$ present had been derived from the radioactive 
diet. The ratio $\alpha_{2}: \alpha_{1}$ would then be equal to the atomic fraction of bone Ca taken up interstitially in the period $t$.

The two rats in group $\mathrm{I}$, which were killed at the age of 3 months, were included in the experiment to provide bones with a large fraction of the cortex deposited from the radioactive dietary $\mathrm{Ca}$ and therefore having the specific activity $\alpha_{1}$. The specific activity ratio $\alpha_{3}: \alpha_{1}$ for the cortical bone in an animal of group 3 would indicate that fraction of radioactive $\mathrm{Ca}$ taken up interstitially during a 2-week period still remaining after a further period on non-radioactive diet.

Serum $\mathrm{Ca}$. The relative specific activities of the pooled serum $\mathrm{Ca}$ from the various pairs of rats were determined by standard counting methods. Ca was precipitated as the oxalate and deposited on a metal disk for the measurement of activity with an endwindow Geiger counter. After counting, the precipitate was dissolved in $\mathrm{N}-\mathrm{H}_{2} \mathrm{SO}_{4}$ and the $\mathrm{Ca}$ content determined by titration with $0.005 \mathrm{~N}-\mathrm{KMnO}_{4}$.

Preparation and measurement of autoradiographs. The specific activities were determined by microdensitometry of autoradiographs prepared from longitudinal sections of the long bones and of the incisor teeth. For the teeth there was no need to refer to the animals of group $\mathrm{I}$, since the more rapid growth provided sufficiently large regions of tooth mineral deposited entirely from radioactive $\mathrm{Ca}$ in the short periods during which the animals of groups 2 and 3 received the radioactive diet. The ratio $\alpha_{2}: \alpha_{1}$, for example, could be determined for a given animal of group 2 from measurements on the appropriate regions in the teeth of that one animal.

Provided that the conditions of preparation of the autoradiographs were carefully controlled, it was found possible to relate in a reproducible manner the measured densities of the appropriate parts of the images to the required specific activities.

The methods of preparation were as described previously by Tomlin et al. (1953) except that a synthetic resin, Ceemar F.R. 264 with hardener F.R. 228 (obtained from Messrs E. M. Cromwell and Co., Bishops Stortford), was used in the embedding medium for the bones and teeth, and Ilford Industrial ' $G$ ' $X$-ray film was used for the autoradiography. It is a high-speed film, which yielded, with exposure times of a few days, satisfactory densities even with the rather weak interstitial activities.

Measurements of the optical densities were made by means of a photomultiplier attachment to a projection microscope used at low magnification. The width of the regions measured was essentially that of the cortex itself, and was thus large enough to permit the use of a low resolution. The width of the photomultiplier slit was in fact nearly one-third of the width of the image of the bone cortex as seen on the microscope screen (see Pl. 2). For this reason the rather large grain size of the fast X-ray film was not a serious disadvantage.

The density of the image of the bone relative to the background of unexposed film was measured at a number of positions along the length of the shaft. Transverse scans of the image were made across the photomultiplier slit at each point. The light intensities $I$ and $I_{0}$, transmitted by the image and by the adjacent unexposed film respectively, were measured. The image density was then defined as $\log _{10} I_{0} / I$.

In measuring the autoradiographs of the bones in group $\mathrm{I}$, care was taken to exclude those parts corresponding to pre-weaning bone, which was present as narrow layers 
within certain parts of the cortex. Autoradiographs corresponding to a range of exposure times were prepared and measured in order to establish a density-exposure time relationship for the reaction of the film to the ${ }^{45} \mathrm{Ca} \beta$-particles.

For anatomical reasons, the autoradiographs of the femora were more convenient for measurements than those of the humeri or tibiae, and most of the measurements were carried out on the femora, but some were made on the humeri for comparison.

Measurements in the incisor teeth were carried out in the same manner as on the long bones.

\section{RESULTS}

Serum $\mathrm{Ca}$. The results are shown in Fig. 2. The specific activity was very nearly constant in all pairs of animals in group 2 at the time of killing, and approximately equal to that of the animals in group $\mathrm{I}$, showing that equilibrium between the serum and dietary $\mathrm{Ca}$ was reached within a time short in comparison with the length of the experimental periods. In the animals of group 3 the specific activity fell rapidly as soon as they were returned to the non-radioactive diet, but remained at a nearly constant low value up to to weeks afterwards.

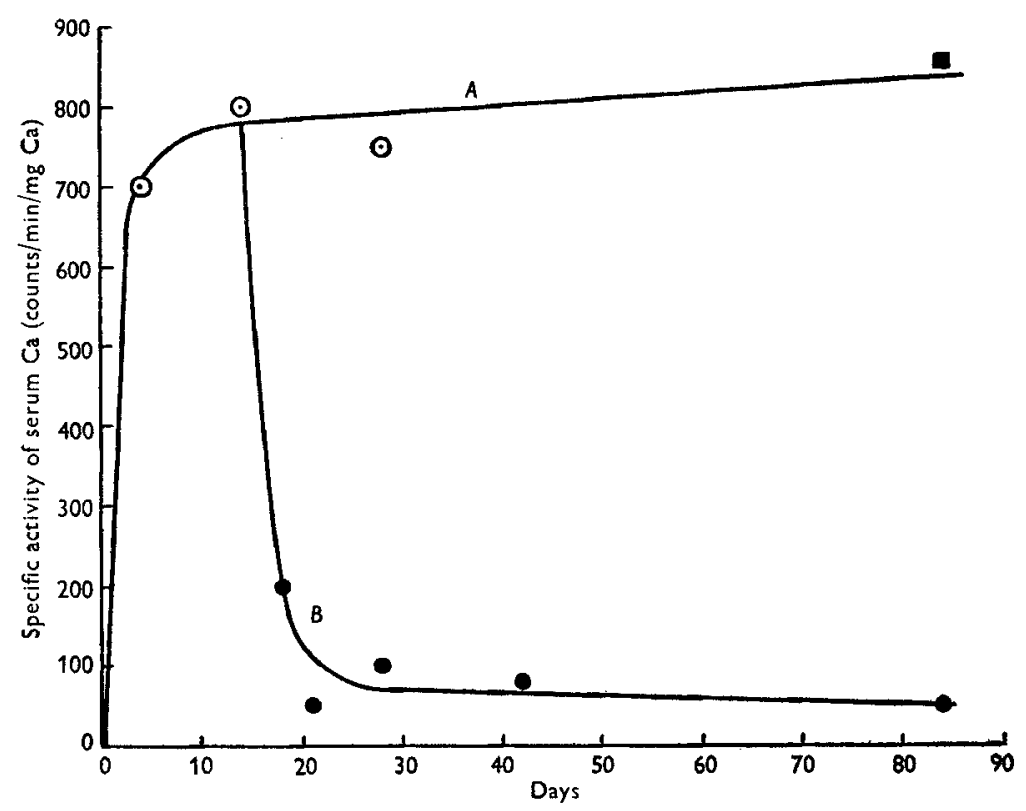

Fig. 2. Time variation of the specific activity of the serum $\mathrm{Ca}$. The points plotted are the values for pairs of rats. Curve $A$ represents the rise to a constant level during continuous feeding of radioactive diet, and curve $B$ the sharp fall on returning the animals to non-radioactive diet. ח, group $\mathrm{I} ; \odot$, group $2 ; \bullet$, group 3 .

Long bones. Pl. I illustrates the gross appearance of representative autoradiographs of femora and of humeri from the three groups, and P1. 2 shows the magnified image as it appeared on the microscope screen during the density measurements. The outline of the photomultiplier slit has been drawn on the photograph to show its relative dimensions. The presence of an approximately uniform diffuse activity throughout 
the cortex of the bones of groups 2 and 3 is clearly shown, together with sharply defined surface layers of comparatively intense activity.

Nearly all the cortical bone in the animals of group I had an apparently uniform activity, since the bone was formed during a long period on the radioactive diet, but narrow layers of the much less active pre-weaning deposit can be seen on the plate. The uniformity of the active regions was confirmed by the density measurements.

Table $\mathrm{x}$. Cortical bone of the femora of animals of group I which received radioactive diet from weaning for a period of 3 months. Autoradiographic density corresponding to full incorporation of radioactive calcium during growth. Exposure times of 1,4 , 8 and 16 h. The values quoted are means for measurements at several points along the length of the bone

\begin{tabular}{|c|c|c|c|c|c|}
\hline $\begin{array}{l}\text { Rat } \\
\text { no. }\end{array}$ & Bone & $\begin{array}{l}\text { Autoradiograph } \\
\text { exposure time } \\
\text { (h) }\end{array}$ & $I^{*}$ & $I_{0} \dagger$ & $\begin{array}{l}\text { Density } \\
\left(\log _{10} I_{0} / I\right)\end{array}$ \\
\hline$I$ & $\begin{array}{l}\text { Left femur } \\
\text { Right femur }\end{array}$ & $\begin{array}{l}\mathbf{I} \\
\mathbf{I}\end{array}$ & $\begin{array}{l}3 \cdot 84 \\
3 \cdot 93\end{array}$ & $\begin{array}{l}4 \cdot 34 \\
4 \cdot 83\end{array}$ & $\begin{array}{l}0.05 \\
0.09\end{array}$ \\
\hline 2 & $\begin{array}{l}\text { Left femur } \\
\text { Right femur }\end{array}$ & $\begin{array}{l}\mathbf{I} \\
\mathbf{I}\end{array}$ & $\begin{array}{l}3 \cdot 63 \\
3 \cdot 62\end{array}$ & $\begin{array}{l}4 \cdot 36 \\
4 \times 40\end{array}$ & $\begin{array}{l}0.08 \\
0.09\end{array}$ \\
\hline & Mean & & & & 0.08 \\
\hline I & $\begin{array}{l}\text { Left femur } \\
\text { Right femur }\end{array}$ & $\begin{array}{l}2 \\
2\end{array}$ & $\begin{array}{l}3 \cdot 15 \\
3 \cdot 13\end{array}$ & $\begin{array}{l}4 \cdot 52 \\
3 \cdot 82\end{array}$ & $\begin{array}{l}0.16 \\
0.19\end{array}$ \\
\hline 2 & $\begin{array}{l}\text { Left femur } \\
\text { Right femur }\end{array}$ & $\begin{array}{l}2 \\
2\end{array}$ & $\begin{array}{l}3 \cdot 13 \\
3 \cdot 15\end{array}$ & $\begin{array}{l}4 \cdot 52 \\
4 \cdot 28\end{array}$ & $\begin{array}{l}0.16 \\
0.13\end{array}$ \\
\hline & Mean & & & & 0.16 \\
\hline I & $\begin{array}{l}\text { Left femur } \\
\text { Right femur }\end{array}$ & $\begin{array}{l}4 \\
4\end{array}$ & $\begin{array}{l}2 \cdot 07 \\
1 \cdot 76\end{array}$ & $\begin{array}{l}4.44 \\
4.01\end{array}$ & $\begin{array}{l}0.33 \\
0.36\end{array}$ \\
\hline 2 & $\begin{array}{l}\text { Left femur } \\
\text { Right femur }\end{array}$ & $\begin{array}{l}4 \\
4\end{array}$ & $\begin{array}{l}1 \cdot 88 \\
2 \cdot 00\end{array}$ & $\begin{array}{l}4: 24 \\
4 \cdot 29\end{array}$ & $\begin{array}{l}0.35 \\
0.33\end{array}$ \\
\hline & Mean & & & & 0.34 \\
\hline $\mathbf{I}$ & $\begin{array}{l}\text { Left femur } \\
\text { Right femur }\end{array}$ & $\begin{array}{l}8 \\
8\end{array}$ & $\begin{array}{l}I \cdot 15 \\
I \cdot 4 I\end{array}$ & $\begin{array}{l}4 \cdot 84 \\
4 \cdot 58\end{array}$ & $\begin{array}{l}0.59 \\
0.51\end{array}$ \\
\hline 2 & $\begin{array}{l}\text { Left femur } \\
\text { Right femur }\end{array}$ & $\begin{array}{l}8 \\
8\end{array}$ & $\begin{array}{l}r \cdot 19 \\
1 \cdot 26\end{array}$ & $\begin{array}{l}4 \cdot 84 \\
4 \cdot 99\end{array}$ & $\begin{array}{l}0.61 \\
0.60\end{array}$ \\
\hline & Mean & & & & 0.58 \\
\hline I & $\begin{array}{l}\text { Left femur } \\
\text { Right femur }\end{array}$ & $\begin{array}{l}16 \\
16\end{array}$ & $\begin{array}{l}0.49 \\
0.50\end{array}$ & $\begin{array}{l}4774 \\
4773\end{array}$ & $\begin{array}{l}0.99 \\
0.98\end{array}$ \\
\hline 2 & $\begin{array}{l}\text { Left femur } \\
\text { Right femur }\end{array}$ & $\begin{array}{l}16 \\
16\end{array}$ & $\begin{array}{l}0.56 \\
0.49\end{array}$ & $\begin{array}{l}4.81 \\
4.63\end{array}$ & $\begin{array}{l}0.93 \\
0.96\end{array}$ \\
\hline & $\begin{array}{l}\text { Mean } \\
\quad \begin{array}{l}* \\
\\
+I_{0}=1\end{array}\end{array}$ & toncit & . & 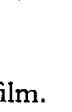 & 0.97 \\
\hline
\end{tabular}

Exposure times for the autoradiographs are listed in the explanation of Pl. I, and it will be seen that much longer exposures were needed to show the diffuse activity in groups 2 and 3 than to show the much more intense reaction due to the growth of radioactive bone in group $\mathrm{I}$. Results of density measurements on autoradiographs of group I, obtained with exposure times of $\mathrm{I}, 2,4,8$ and $\mathrm{I} 6 \mathrm{~h}$, are given in Table $\mathrm{I}$, and the average values for each time are plotted in Fig. 3. To show the actual observations made, photomultiplier current readings are included in the table. 
A comparison (Table 2) between the densities measured in autoradiographs of femora and of humeri of group I showed no significant difference between the two bones, and the combined mean values from this table are included in Fig. 3. These autoradiographs were processed separately from those referred to in Table $\mathbf{I}$, and the agreement indicates good reproducibility of the processing conditions.

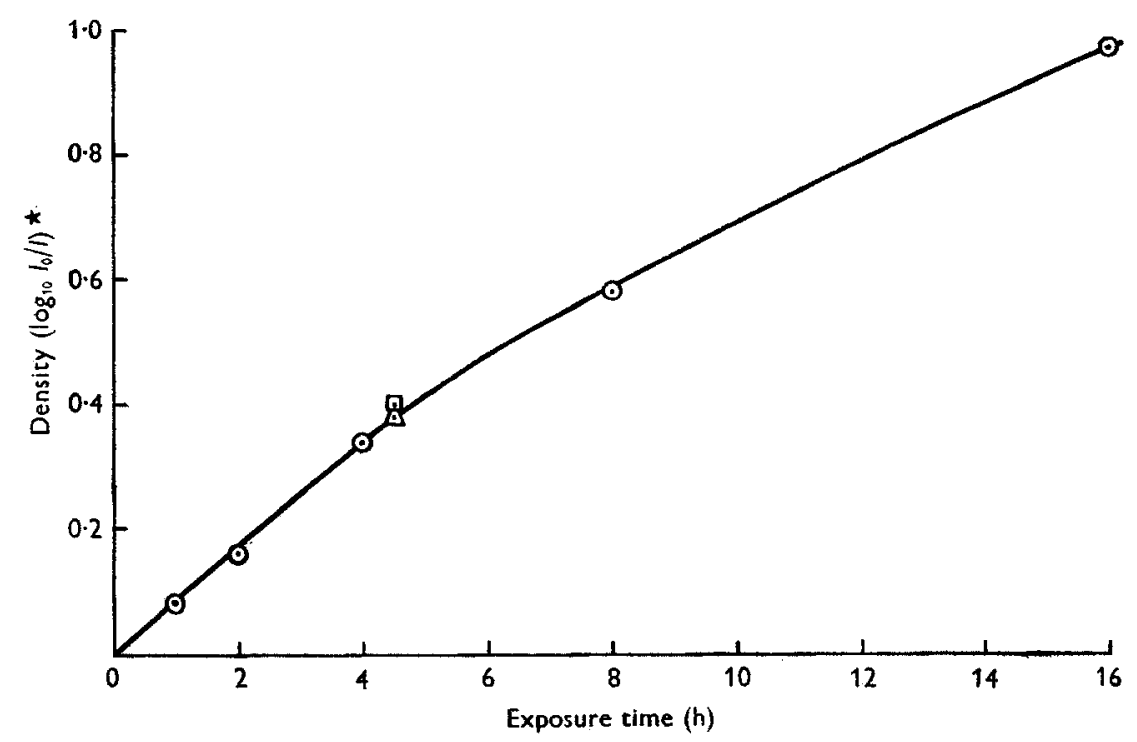

Fig. 3. Density-exposure time curves for the autoradiographic reaction due to radioactive growth in the bones of rats of group $\mathrm{I} . \odot$, results from Table $1 ; \square$, results from Table 2 (femur); $\Delta$, results from Table 2 (humerus).

* See Table $\mathbf{~}$.

Table 2. Cortical bone of femora and humeri of animals of group I. Comparison of autoradiographic densities in femora and in humeri. Exposure time $4.5 \mathrm{~h}$. The values quoted are means for measurements at several points along the length of the bone

\begin{tabular}{clc} 
Rat & \multicolumn{1}{c}{ Bone } & Density \\
no. & Left femur & $\left(\log _{10} I_{0} / I\right)^{*}$ \\
I & Right femur & $0 \cdot 4 \mathrm{r}$ \\
& Left humerus & $0 \cdot 4 \mathrm{I}$ \\
& Right humerus & $0 \cdot 36$ \\
& Left femur & $0 \cdot 39$ \\
2 & Right femur & $0 \cdot 38$ \\
& Left humerus & $0 \cdot 37$ \\
& Right humerus & 0.38 \\
& * See Table $\mathrm{x}$. &
\end{tabular}

The measured densities corresponding to the diffuse interstitial activities in the autoradiographs of groups 2 and 3 are given in Tables 3 and 4 respectively. Again no significant variation along the length of the shafts was detected, and the figures quoted in the tables are means of the densities measured at a number of positions.

Incisors. Representative autoradiographs from one animal of each of groups 2 and 3 are shown in Pl. 3. Layers of new dentine and of enamel formed during the 
radioactive periods are clearly defined. These results support those from measurements of the specific activity of serum $\mathrm{Ca}$ by showing a uniform activity throughout the radioactive growth zone, and a persistent low activity after the return to nonradioactive diet in the animals of group 3 .

Table 3. Cortical bone of rats of group 2 which received radioactive diet for periods of up to 4 weeks. Autoradiographic densities corresponding to radioactive calcium incorporated interstitially

Days on

${ }^{45} \mathrm{Ca}$ diet

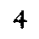

4

7

7

$x_{4}$

28

\section{Bone}

Rat no. 3, femora Rat no. 4, femora

Rat no. 3, femora Rat no. 4, femora

Rat no. 5, femora

Rat no. 5, humeri

Rat no. 6, femora

Rat no. 6, humeri

Rat no. 5, femora

Rat no. 6, femora

Rat no. 7, femora

Rat no. 7, humeri

Rat no. 8, femora

Rat no. 8, humeri

Rat no. 9, femora

Rat no. 9, humeri

Rat no. 1o, femora

Rat no. 1o, humeri

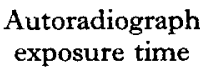

(h)

71

$7 \mathrm{x}$

144

144

71

7 I

71

71

144

I 44

71

71

71

71

71

$7 \mathrm{r}$

71

Density
$\left(\log _{10} I_{0} / I\right)^{*}$
0.04
0.04
0.09
0.10
0.06
0.06
0.06
0.08
0.14
0.12
0.13
0.11
0.11
0.13
0.21
0.21
0.23
0.20

* See Table $\mathbf{~}$.

Table 4. Cortical bone of rats of group 3 which received non-radioactive diet after a 2-week period of radioactive diet. Autoradiographic densities corresponding to retention of radioactive dietary calcium incorporated interstitially

\begin{tabular}{|c|c|c|c|}
\hline $\begin{array}{l}\text { Days after } \\
\text { 14-day period } \\
\text { on }{ }^{45} \mathrm{Ca} \text { diet }\end{array}$ & Bone & $\begin{array}{l}\text { Autoradiograph } \\
\text { exposure time } \\
\text { (h) }\end{array}$ & $\begin{array}{c}\text { Density } \\
\left(\log _{10} I_{0} / I\right)^{*}\end{array}$ \\
\hline 4 & $\begin{array}{l}\text { Rat no. I I, femora } \\
\text { Rat no. I } 2 \text {, femora }\end{array}$ & $\begin{array}{l}\text { I } 44 \\
\text { I } 44\end{array}$ & $\begin{array}{l}0.23 \\
0.24\end{array}$ \\
\hline 7 & $\begin{array}{l}\text { Rat no. } 13 \text {, femora } \\
\text { Rat no. } 14 \text {, femora }\end{array}$ & $\begin{array}{l}144 \\
144\end{array}$ & $\begin{array}{l}0.22 \\
0.26\end{array}$ \\
\hline 14 & $\begin{array}{l}\text { Rat no. } 15 \text {, femora } \\
\text { Rat no. } 16 \text {, femora }\end{array}$ & $\begin{array}{l}144 \\
144\end{array}$ & $\begin{array}{l}0.25 \\
0.26\end{array}$ \\
\hline 28 & $\begin{array}{l}\text { Rat no, } 17 \text {, femora } \\
\text { Rat no. } 18 \text {, femora }\end{array}$ & $\begin{array}{l}144 \\
144\end{array}$ & $\begin{array}{l}0.22 \\
0.24\end{array}$ \\
\hline 70 & $\begin{array}{l}\text { Rat no. I9, femora } \\
\text { Rat no. } 20, \text { femora }\end{array}$ & $\begin{array}{l}144 \\
144\end{array}$ & $\begin{array}{l}0.22 \\
0.21\end{array}$ \\
\hline
\end{tabular}

In the parts of the teeth deposited before the radioactive periods, which could incorporate ${ }^{45} \mathrm{Ca}$ only interstitially, an autoradiographic reaction was hardly detectable even with a very long exposure (see $\mathrm{Pl} .3$ ). With an exposure time of 7 days there was not a significant difference between the optical densities of this region of the autoradio- 
graph and those of the unexposed part of the film. An exposure time of $20 \mathrm{~min}$ was sufficient to give a definitely observable density corresponding to the zone of radioactive growth.

Table 5. Interstitial uptake of Ca expressed as percentage of total

$\mathrm{Ca}$ in bones of rats in group 2

$\begin{array}{ccc}\begin{array}{c}\text { Days on } \\ \text { radioactive } \\ \text { diet }\end{array} & \begin{array}{c}\text { Autoradiograph } \\ \text { exposure time }\end{array} & \begin{array}{c}\text { Uptake of } \\ \text { radioactive Ca }\end{array} \\ 4 & \text { (h) } & 0.70 \\ 4 & 71 & 0 \cdot 76 \\ 7 & 144 & 1 \cdot 13 \\ 7 & 71 & 1 \cdot 01 \\ 14 & 144 & 1 \cdot 97 \\ 28 & 71 & 3.52\end{array}$

Table 6. Retention of Ca taken up interstitially expressed as percentage of total $\mathrm{Ca}$ in bones of rats in group 3

$\begin{array}{ccc}\begin{array}{c}\text { Days after } \\ \text { I4-day period } \\ \text { on radioactive }\end{array} & \begin{array}{c}\text { Autoradiograph } \\ \text { exposure time }\end{array} & \begin{array}{c}\text { Uptake of } \\ \text { diet }\end{array} \\ \text { (h) } & \text { radioactive Ca } \\ 4 & 144 & 1 \cdot 94 \\ 7 & 144 & 2 \cdot 01 \\ 14 & 144 & 2 \cdot 12 \\ 28 & 144 & 1 \cdot 92 \\ 70 & 144 & 1 \cdot 93\end{array}$

Calculation of the interstitial uptake. The percentage of bone-Ca atoms taken up interstitially was calculated from the foregoing results as follows. If the specific activity of a region of bone mineral is defined as the percentage of ${ }^{45} \mathrm{Ca}$ atoms in the total bone $\mathrm{Ca}$, the 'exposure' $E$ of the $\mathrm{X}$-ray film in contact with the surface of the section for an 'exposure time' $t$, may be expressed as $E=\mathrm{K} \alpha t . K$ is a constant which takes account of the effective thickness of the section, the absorption of the $\beta$-particles within it, and the sensitivity of the film. The measured densities will be immediately related to the corresponding values of $E$, and if two regions of bone with specific activities $\alpha_{1}$ and $\alpha_{2}$ give the same density $d$ with exposure times $t_{1}$ and $t_{2}$, it follows that the $E$ values must also be the same, and therefore $K \alpha_{1} t_{1}=K \alpha_{2} t_{2}$, and $\alpha_{2} / \alpha_{1}=t_{1} / t_{2}$. Suppose $\alpha_{2}$ and $t_{2}$ refer to the interstitial activity in a bone of group 2, giving rise to a measured density $d$. If $\alpha_{1}$ is the specific activity of the same region of a bone of group $\mathrm{I}$, due in this instance to full incorporation of the dietary ${ }^{45} \mathrm{Ca}$ during growth, the value of $t_{1}$ that would give the same measured density $d$ can be read from the graph in Fig. 3, and so the ratio $\alpha_{2}: \alpha_{1}$ can be deduced. From the definition of specific activity it follows that this ratio is equal to the fraction of cortical bone $\mathrm{Ca}$ that has entered the bone of group 2 interstitially in a given time interval.

The mean results of the calculation for each of the four experimental periods in group 2 are given in Table 5 and as a graph of percentage uptake against time in Fig. 4 . Calculations made in the same way from the results for the animals of group 3 are given in Table 6, and plotted in Fig. 5 . 
Since the interstitial uptake of $\mathrm{Ca}$ by the incisors was near the limit of detection, only an upper limit can be estimated from the exposure times referred to on p. 150 . With $t_{1}=20 \mathrm{~min}$ and $t_{2}>7 \times 24 \times 60 \mathrm{~min}$ for the 4 -week interval in group $\mathrm{I}$, the percentage $\mathrm{Ca}$ uptake by the incisor dentine must be less than $100 t_{1} / t_{2}$, i.e. $<0.2$ in 4 weeks or $<0.05$ per week.

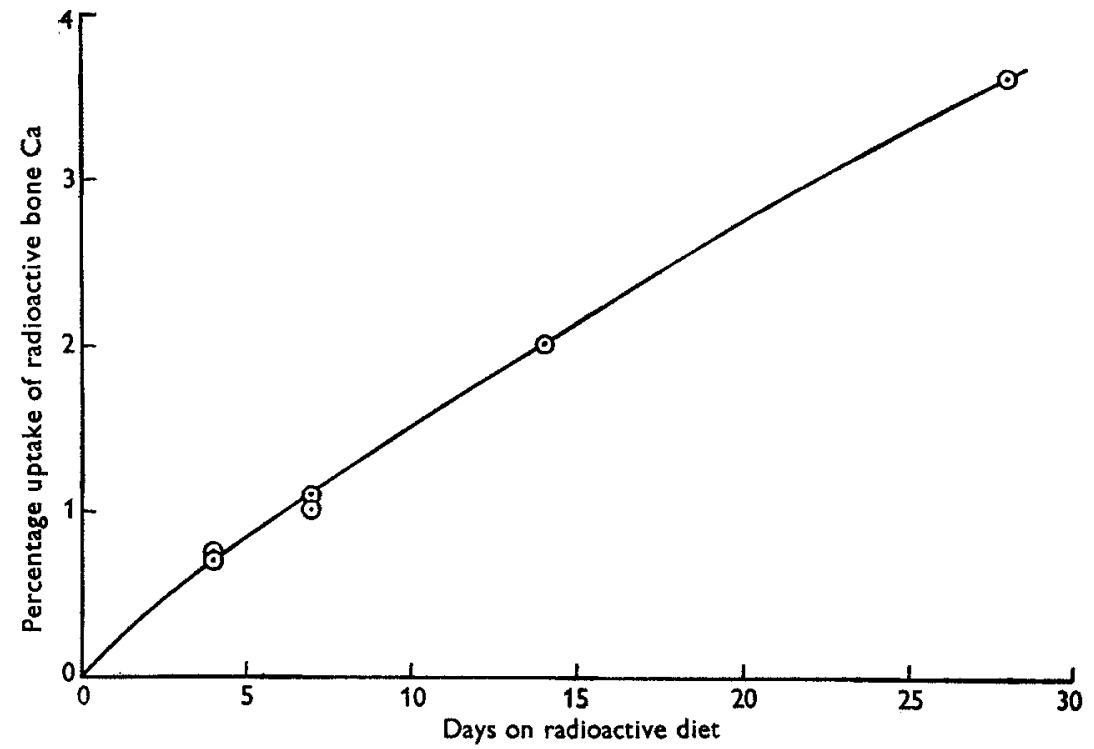

Fig. 4. Interstitial uptake of $\mathrm{Ca}$ in the cortical bone of the rats of group 2.

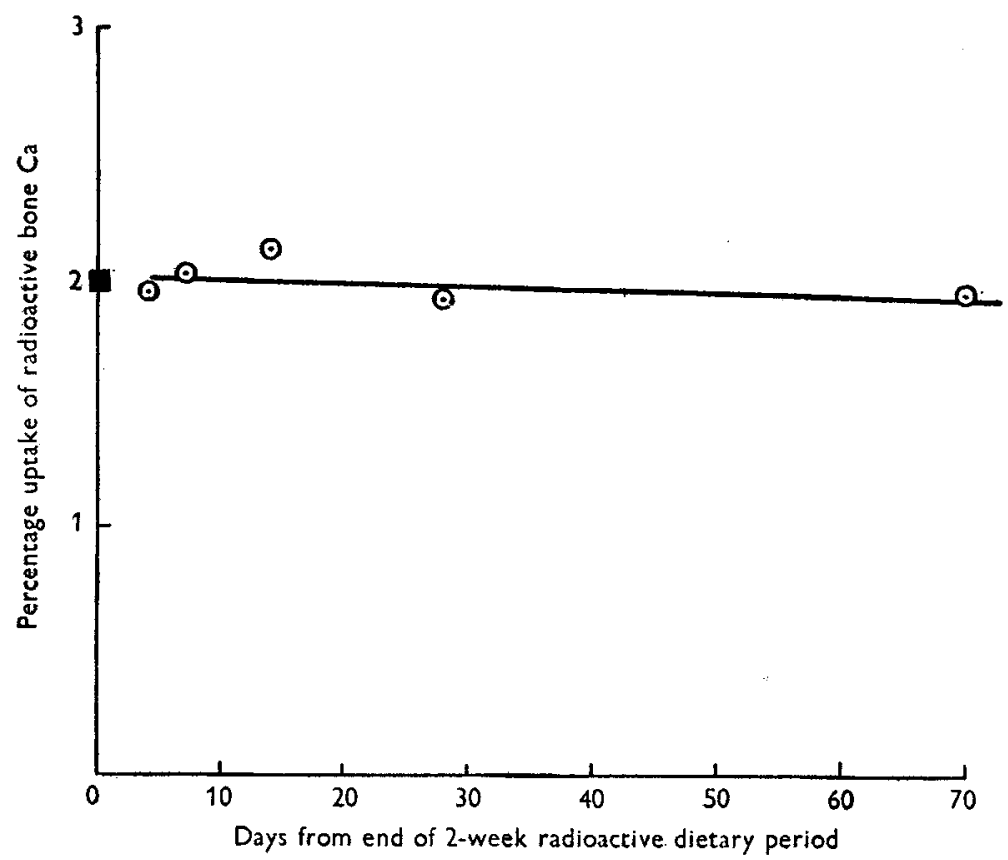

Fig. 5. Retention of $\mathrm{Ca}$ taken up interstitially in the cortical bone of the rats of group 3. The point marked $\square$ represents the value for the pair of rats of group 2 that received the radioactive diet for 2 weeks. 
The use of a diet of constant composition throughout the experiment ensured as far as possible that all the bones examined had a similar composition, and therefore the same characteristics for the absorption of the ${ }^{45} \mathrm{Ca} \beta$-particles. Since these characteristics define an effective section thickness it is reasonable to assume that $K$ was in fact constant for all the sections, and that the method of calculation is justified. This supposition was confirmed experimentally by the good agreement among the several measurements within each group.

\section{DISCUSSION}

Evidence from the measurement of the specific activity of serum $\mathrm{Ca}$, and the autoradiographs of the incisors, indicates that equilibrium between serum $\mathrm{Ca}$ and dietary $\mathrm{Ca}$ was reached sufficiently quickly for the measured ratio of accumulation of radioactive $\mathrm{Ca}$ in the bone and tooth mineral to be determined by rate-determining processes within these tissues. The smoothness of the curves that could be drawn through the experimental points in Figs. 4 and 5 suggests the predominance of a single process rather than a competition between two or more processes with widely different rates.

The curve in Fig. 4 might be regarded as the beginning of an exponential function of the form $f(t)=A\left(\mathrm{I}-e^{-\lambda t}\right)$, where $f(t)$ is the fraction of Ca atoms that entered the bone mineral in time $t, \lambda$ a rate constant, and $A$ a saturation limit. If more experimental points near the origin were available, the smooth extrapolation to the origin might be shown in error. It is possible that there is an initial sharp rise in the curve, for the experimental points fit closely to a straight line which intercepts the vertical axis at about $0.2 \% \mathrm{Ca}$. However, it is clear that the predominant effect is a slow accumulation of radioactive $\mathrm{Ca}$ which, according to $\mathrm{Fig}$. 5 , is mostly retained for a long period. The rate of accumulation of $\mathrm{Ca}$ of $\mathrm{I} \%$ per week gives $\lambda=1 \cdot 4 \times 10^{-3}$ per day, and a 'half period' of 500 days as the time required for $f$ to reach half the saturation limit.

The most direct interpretation of the results is that, in the 3 -month-old animals used in the experiments, $\mathrm{Ca}$ is taken up interstitially by cortical bone as part of the general mineralization of the skeleton. Such an uptake forms no part of the bonegrowth mechanism since it does not lead to an increase in the dimensions of the bone, but it does represent an increase in the total $\mathrm{Ca}$ content of the bone mineral. Henry \& Kon (1953, Table 3 ) have shown that the percentage content of $\mathrm{Ca}$ in the long bones of rats fed on the same diet as used in the present work continues to increase until the animals reach an age of about 6 months. At the age of 3 months, the Ca content was found to increase at about $\mathrm{I} \%$ per week, a result agreeing with the rate of uptake measured in the present experiments.

Such an interstitial accretion of bone mineral can be understood in terms of the addition of new crystals to the organic matrix, continuing for some time after its formation, or of the growth of existing crystals. On account of the difficulty in observing the individual crystals, it is not known whether their subsequent growth does or does not occur. 
Since our measurements were on a macroscopic scale we are not justified at present in drawing any conclusions about the fine mechanism of the interstitial accretion. It may well not be uniform throughout the bone but involve preferentially localized regions of remodelling incapable of resolution by our technique. Be that as it may, the specific activities derived from the autoradiographs represent to our mind the summation of interstitial processes of Ca metabolism, and the curves in Figs. 4 and 5 the variation in time of this total effect.

The results do not show an appreciable exchange effect of the kind discussed by Neuman \& Neuman (1953) and Neuman \& Weikel (1954). Exchange of bone Ca is supposed to take place between the crystal surfaces and the body fluids. Radioactive Ca supplied continuously to the circulation is taken up by a certain available fraction of the total crystal surface, a saturation limit being reached when ions in all the available surface sites have exchanged with the radioactive body-fluid $\mathrm{Ca}$.

Neuman \& Weikel (I954) have published an experimental curve of the total amount of radioactive $\mathrm{Ca}$ taken up by the bones of $200 \mathrm{~g}$ rats as a function of time on a radioactive diet, and have analysed the curve into three components representing (a) surface exchange, $(b)$ uptake due to Haversian remodelling, and $(c)$ accretion of new bone mineral due to bone growth. They conclude that $4 \%$ of the femur $\mathrm{Ca}$ is available for rapid exchange.

A very much lower value is obtained if the same method of analysis is applied to the curve of Fig. 4 which, on account of the method of measurement, does not include the bone-growth component. Only the exchange effect, and the gradual accretion due to Haversian remodelling or, as seems more probable, to an actual increase in the bone $\mathrm{Ca}$, will be present. The method of analysis consists in extrapolating the curve to zero time and measuring the intercept on the vertical axis, which represents the initial rapid uptake of exchanged $\mathrm{Ca}$.

As mentioned on p. I 53 this calculation gives, for the fraction of cortical bone Ca available for rapid exchange, a value not greater than $0.2 \%$. Since the exchange effect should be reversible, the curve of Fig. 5 should show an initial fall of the same amount, but this is not in fact shown. Such a small effect is, however, close to the experimental errors, and not easily detectable, and the results from groups 2 and 3 are therefore consistent with the existence of an exchangeable fraction in cortical bone of not more than $0.2 \%$.

Neuman \& Weikel ( 1954 ) do not give details of the methods used for determining the percentage uptake of radioactive $\mathrm{Ca}$, but it appears that the whole femur may have been assayed for radioactive and total $\mathrm{Ca}$. If this is so, their values for both the exchanged fraction and the interstitial uptake will represent means for the different types of bone material present. Since the availability of the mineral salts to the circulation must be a major factor controlling the degree of exchange, there is every reason to suppose that, for example, $\mathrm{Ca}$ in cancellous bone exchanges much more readily than $\mathrm{Ca}$ in compact cortical bone to which the present measurements are restricted. Such considerations may account for the difference between the present result and that of Neuman \& Weikel (1954). 
D. H. TOMLin, KATHLEen M. HENRY and S. K. KON. The interstitial Plate I METABOLISM OF CALCIUM IN THE BONES AND TEETH OF RATS

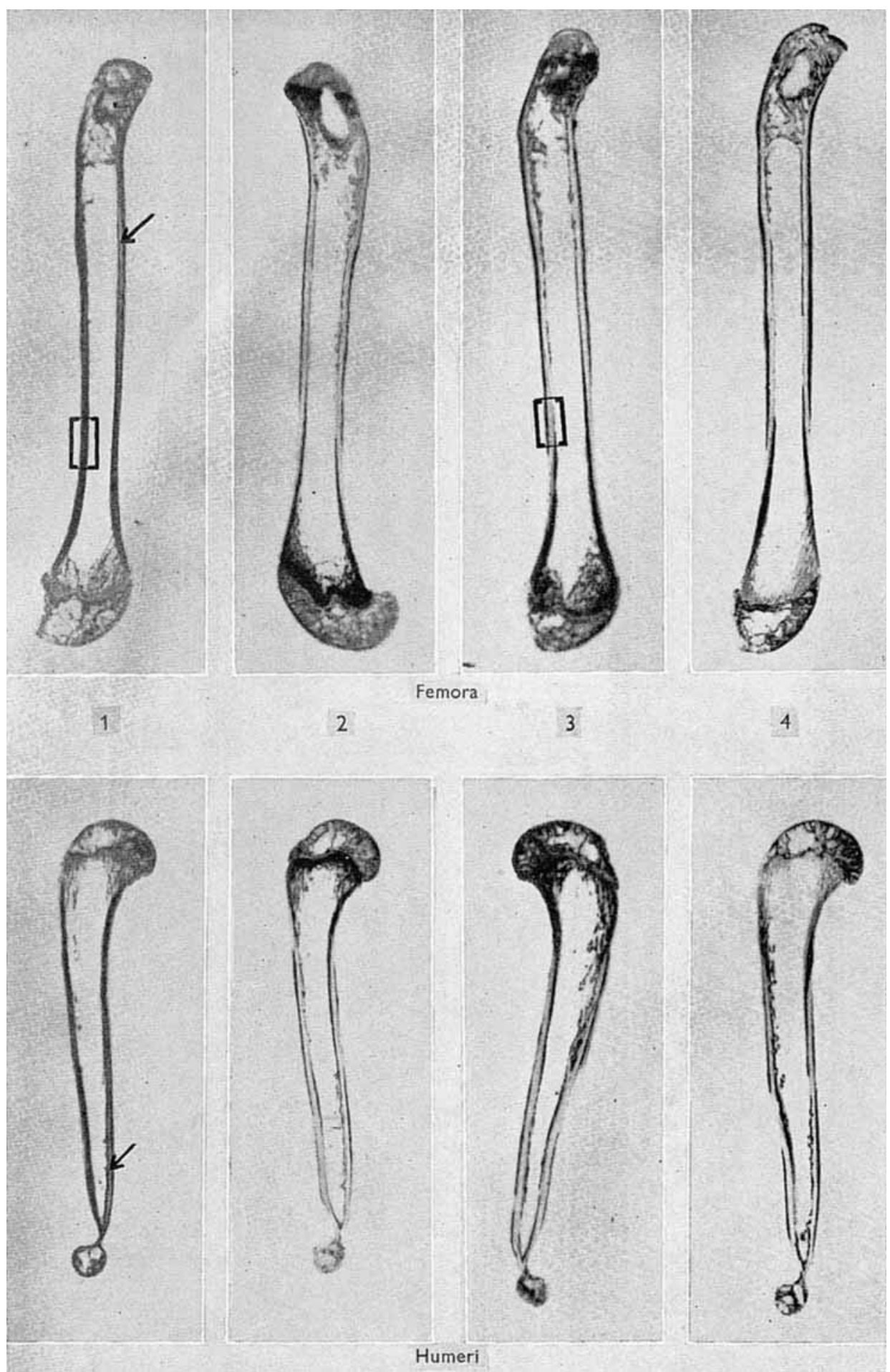

British Yournal of Nutrition, Vol. 9, No. 2

(Facing page 154) 
D. H. TOMLin, KathleEn M. Henry and S. K. KON. The interstitial Plate 2 METABOLISM OF CALCIUM IN THE BONES AND TEETH OF RATS

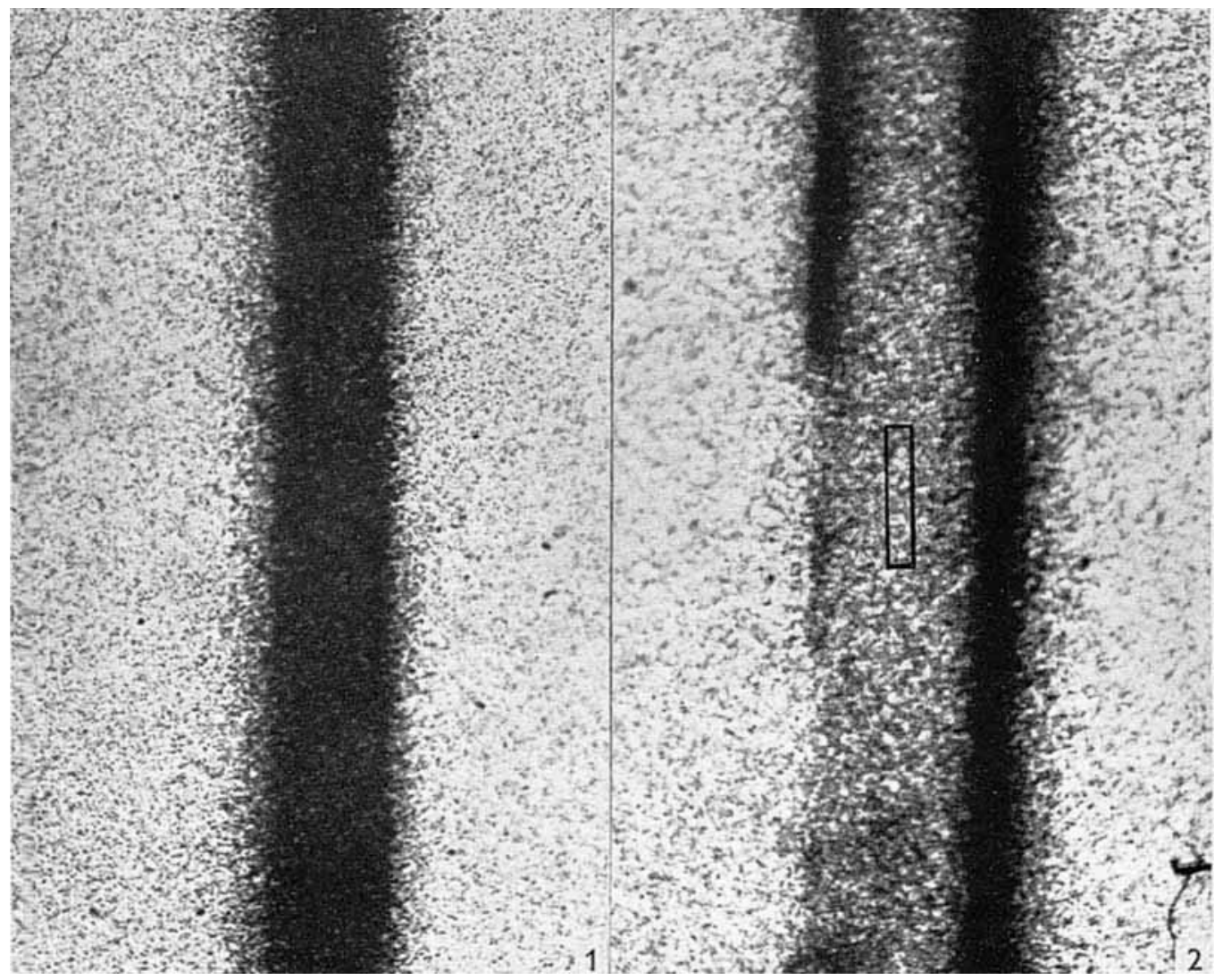

British Fournal of Nutrition, Vol. 9, No. 2 
D. H. TOMLin, KathleEn M. HenRY and S. K. KON. The interstitial Plate 3 METABOLISM OF CALCIUM IN THE BONES AND TEETH OF RATS

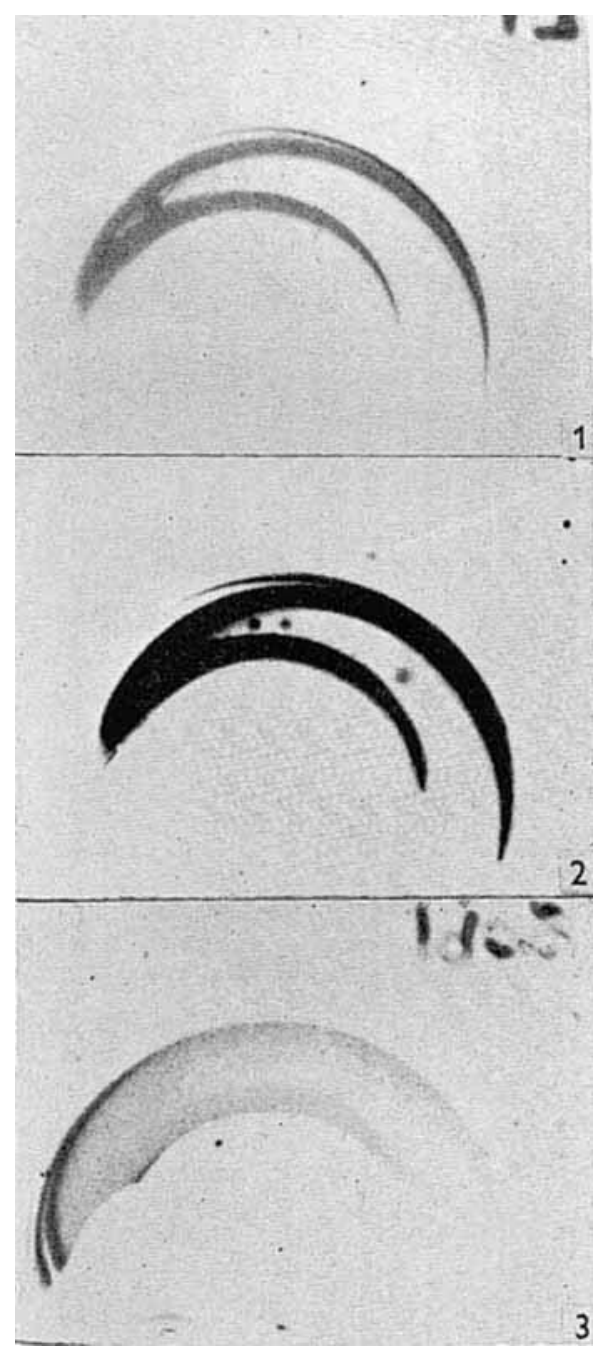

British Fournal of Nutrition, Vol. 9, No. 2 
I. Autoradiographs from longitudinal sections of the long bones of rats fed for specific periods on a diet containing radioactive ${ }^{45} \mathrm{Ca}$ showed two distinct processes of Ca uptake. These are due to the surface accretion of new bone mineral, and to an interstitial uptake in the previously deposited mineral.

2. Measurements of the percentage uptake of interstitial $\mathrm{Ca}$ in the cortical bone and incisor dentine of 3 -month-old rats have been made by a method of quantitative autoradiography. Continuous administration of the isotope in the diet led to a nearly constant level of specific activity of serum Ca throughout the periods in which it was given.

3. The interstitial uptake was found to follow a smooth time curve, at a rate of about $\mathrm{r} \%$ of the total cortical bone $\mathrm{Ca}$ per week. This figure agrees with previous values (Henry \& Kon, 1953) for the percentage rate of accretion of bone $\mathrm{Ca}$.

4. The exchangeable fraction of cortical bone $\mathrm{Ca}$ appeared to be so small as to be near the limit of detection, and was estimated at $<0.2 \%$.

5. The total interstitial uptake of radioactive $\mathrm{Ca}$ in incisor dentine was very much less than in bone, and was estimated at $<0.05 \%$ per week.

6. It is concluded that the predominant effect in interstitial metabolism of $\mathrm{Ca}$ in the bones of growing rats ( 3 months old), on the diet used in these experiments, is a non-reversible uptake, or interstitial accretion, with only a very small contribution due to a reversible exchange process.

The authors wish to acknowledge the valuable assistance given by Miss M. V. Chapman in the care and feeding of the experimental animals and by Mrs E. M. Wiltshire in preparing bone sections and autoradiographs.

\section{REFERENCES}

Bauer, G. C. H. (1954). F. Bone Jt. Surg. 36A, 375.

Carlsson, A. (1952). Acta physiol. scand. 26, 200.

Henry, K. M. \& Kon, S. K. (1953). Brit. F. Nutr. 7, 147.

Neuman, W. F. \& Neuman, M. W. (1953). Chem. Rev. 53, $x$.

Neuman, W. F. \& Weikel, J. H. Jr. (1954). The Recrystallization of Bone Mineral. University of Rochester Atomic Energy Project. Report U.R. 314. (Mimeo.).

Tomlin, D. H., Henry, K. M. \& Kon, S. K. (1953). Brit. F. Nutr. 7, 235.

\section{EXPLANATION OF PLATES}

Plate I

Representative autoradiographs of femora and humeri from the three experimental groups of rats. Note that the surface growth layers remain apparently unchanged except for the remodelling at the growing ends of the bones.

I. Group I. Given the radioactive diet for 3 months. Exposure time $8 \mathrm{~h}$. Note the uniform radioactivity except for the layers of pre-weaning bone mineral indicated by an arrow. The rectangle denotes the region enlarged in Pl. 2.

2. Group 2. After I week on radioactive diet. Exposure time $144 \mathrm{~h}$. The interstitial uptake is shown by a faint activity throughout the cortex. 
3. Group 2. After 2 weeks on radioactive diet. Exposure time $144 \mathrm{~h}$. The rectangle indicates the region enlarged in Pl. 2.

4. Group 3. Ten weeks after returning to non-radioactive diet. The interstitial activity is still comparable with that in 3 .

Plate 2

Photomicrographs of cortical regions of the autoradiographs.

1. Group 1. Uniform activity due to full incorporation of the radioactive diet during growth.

2. Group 2. The photomicrograph shows the uniformity of the interstitial activity throughout the thickness of the pre-radioactive cortical bone. The outline of the photomultiplier slit is superposed on the photograph.

Plate 3

Autoradiographs of upper incisors.

1. Group 2. After 4 weeks on radioactive diet. Exposure time $4 \mathrm{~h}$. Only the uniformly radioactive growth zone in the dentine, and new growth of enamel is revealed.

2. Same as $\mathrm{I}$, exposure time $\mathbf{8}$ days. Even with a very long exposure no interstitial activity in the preradioactive dentine is detectable.

3. Group 3. Ten weeks after return to non-radioactive diet. In this interval nearly the whole tooth has been renewed by growth. The variation with time of the serum-Ca activity has been recorded in the deposited dentine which shows the persisting activity due to the return of resorbed radioactive bone mineral to the circulation.

\title{
Growth and Amino-acid Intakes of Children on a Cereal- Legume-Vegetable Diet
}

\author{
By N. G. BAP'TIST AND BEA'TRICE V. DE MEL \\ Biochemical Laboratory, Department of Physiology, \\ University of Ceylon, Colombo, Ceylon
}

(Received 4 September 1954)

Opinion is as yet divided on the adequacy of vegetable protein as the sole protein in the diet of growing children. On the one hand, Woolley (1945) has demonstrated the existence of a growth factor associated with certain proteins. On the other hand, vitamin $B_{12}$, which is present in plants in scarcely detectable amounts (Smith, 1950-I), has been claimed to be necessary for optimum growth (Zucker \& Zucker, 1948; Maddy \& Swift, I952). In recent papers (Chick, I95 I ; Nicol, 1952) the low biological value of vegetable proteins has been ascribed to deficiency in certain of the essential amino-acids, especially lysine and tryptophan. Clinical findings in infants and children fed on predominantly vegetable diets have shown such varied features as low serum albumin, oedema, fatty liver, anaemia and symptoms resembling those arising from B-vitamin deficiencies (Brock \& Autret, 1952) all of which occur in the condition called kwashiorkor or malignant malnutrition. It is now recognized that kwashiorkor is liable to occur in all races (Williams, I953) and is amenable to treatment with skim milk, the curative factor being either the essential amino-acids of the milk proteins or a growth factor associated with the animal protein and designated animal protein factor (APF). 